metabolic disorder and therefore do not lose weight as a result of phenformin administration, even though phenformin therapy results in a significant reduction in insulin levels, if raised, in those subjects (Grodsky et al., 1963). Possibly this is due to the fact that hepatic gluconeogenesis is unimpaired in obese non-diabetics (Kreisberg, 1968; Searle and Cavalieri, 1968).

We wish to thank Mrs. D. M. Dezsi, S.R.D., the dietitian who assisted in this trial.

This work was supported by a grant from the Bayer Products Company, who also provided the phenformin and placebo capsules.

\author{
REFERENCES
}

Bloom, A. (1968). British fournal of Hospital Medicine, 2, 766.

Boshell, B. R., Roddam, R. F., and McAdams, G. L. (1968). Annals of the New York Academy of Sciences, 148, 756.
Butterfield, W. J. H. (1968). Annals of the New York Academy of Sciences,

148, 724. (1968). Diabetes, 17, 492.

Fajans, S. J., Moorhouse, J. A., Doorenbos, H., Louis, L. H., and Conn, J. W. (1960). Diabetes, $9,194$.

Faludi, G., Chayes, Z., and Gerber, P. (1968). Postgraduate Medicine, 43, 92. Grodsky, G. M., Karam, J. H., Pavlatos, F. C., and Forsham, P. H. (1963).
Metabolism, 12, 278.

Kreisberg, R. A. (1968). Diabetes, 17, 481.

Lyngsøe, J., and Trap-Jensen, J. (1969). British Medical fournal, 2, 224.

Munro, J. F., MacCuish, A. C., Marshall, A., Wilson, E. M., and Duncan, L. J. P. (1969). British Medical fournal, $2,13$.

Patel, D. P., and Stowers, J. M. (1964). Lancet, 2, 282

Roginsky, M. S., and Barnet, J. (1966). American fournal of Clinical Nutrition, $19,223$.

Roginsky, M. S., and Sandler, J. (1968). Annals of the New York Academy of Sciences, 148, 892.

Sadow, H. S. (1962). Applied Therapeutics, 4, 369.

Searle, G. L., and Cavalieri, R. R. (1968). Annals of the New York Academy of Sciences, 148, 734.

\title{
Comparison between Local Injections of Silicone Oil and Hydrocortisone Acetate in Chronic Arthritis
}

\author{
MARY CORBETT ${ }^{*}{ }^{\text {M.B., }}$ M.R.C.P. ; MARTIN H. SEIFERT, $\dagger$ M.B., B.S. ; CELIA HACKING, $\ddagger$ M.C.S.P. ; \\ SYLVIA WEBB, $\ddagger$ M.C.S.P.
}

British Medical fournal, 1970, 1, 24-25

Cummary: One of three preparations-silicone oil, $S_{\text {hydrocortisone acetate, and hydrocortisone acetate }}$ plus saline-was injected into 22 osteoarthritic and 49 rheumatoid knees. Silicone injected into stiff, dry, grating knees which were the site of chronic arthritis did not promote better movement than did hydrocortisone alone. Hydrocortisone plus saline, however, appeared to be more effective than silicone or hydrocortisone alone in increasing movement in rheumatoid knees. The maximum increase in movement was found to occur three weeks after each of the three different injection preparations.

\section{Introduction}

Helal and Karadi (1968) reported excellent results in stiff, dry, grating joints after injection of silicone oil. Their study was uncontrolled, however, and for this reason it was decided to compare the results of silicone oil with hydrocortisone acetate injected into stiff knees.

\section{Materials and Methods}

All patients admitted to the trial suffered from arthritis of the knees and were currently attending the department of rheumatology and physical medicine at the Middlesex Hospital. One group of patients appeared to have primary degenerative joint disease for which no underlying cause could be found. The second group had degenerative changes superimposed on rheumatoid disease. All patients had a history of pain and stiffness in the knees of at least 10 years' duration and all had received intra-articular hydrocortisone acetate in the past. The range of movement in knees included in this trial did not exceed $100^{\circ}$.

Each patient was asked if he or she would be willing to try the effect of a "new" injection and to attend the physiotherapy department to be given twice-weekly quadriceps exercises for six weeks following the injection $X$-ray films were taken before the injection and at the end of the assessment period six months later.

Thirteen patients (age range 65-83 years) with 22 osteo-

*Consultant Physician.

tFormerly Registrar.

¥Formerly Staff Physiotherapist.

Department of Rheumatology and Physical Medicine, the Middlesex Hospital, London W.1. arthritic knees and 34 (age range 44-79 years) with 55 rheumatoid knees were admitted to the trial.

Each knee was numbered on entry to the trial, the right receiving the lower number when both knees were injected. After the initial assessment (by M.C. and either C.H. or S.W.), one of three injections was given by M.H.S. according to a random list known to him alone.

The three injections used were $10 \mathrm{ml}$. of silicone oil (M.S. 200/200 centistoke made by Midland Silicones Ltd.), $2 \mathrm{ml}$. (50 mg.) of hydrocortisone acetate, or $2 \mathrm{ml}$. of hydrocortisone acetate diluted with $10 \mathrm{ml}$. of normal saline. The latter was used in an attempt to match the bulk of the silicone oil injection. As the aim of this study was to find out only whether injections of silicone were any more effective than hydrocortisone, no placebo was used.

M.C. and either C.H. or S.W. performed initial baseline and subsequent assessments which were carried out weekly for six weeks and then at 12 and at 24 weeks after the injection. The relevant history and clinical findings were noted on a detailed form. The range of movement in the knee was measured with a goniometer, and the amount of weight in pounds which could be lifted 10 times by the contracted quadriceps muscle was recorded on each occasion. The patient was asked whether the pain was better, worse, or the same.

Seventy-seven knees were admitted to the trial. Two patients with rheumatoid arthritis were withdrawn when they were admitted for an elective arthrodesis, one patient with rheumatoid arthritis severely affecting both knees was admitted to another hospital, and another rheumatoid patient was unable to complete the assessment period. The results, therefore, are based on a study of 71 knees, 22 with osteoarthritis and 49 with rheumatoid arthritis.

\section{Results}

The terminology used is that recommended by the American Academy of Orthopaedic Surgeons (1966).

The mean of initial flexion in the 22 osteoarthritic knees was $92.7^{\circ}$ (range $60^{\circ}-105^{\circ}$ ), and the mean of initial extension loss was $16.9^{\circ}$ (range $10^{\circ}-35^{\circ}$ ). In the 49 rheumatoid knees the mean of initial flexion was $95.6^{\circ}$ (range $55^{\circ}-125^{\circ}$ ) and of initial extension loss $21.7^{\circ}$ (range $10^{\circ}-45^{\circ}$ ). Analysis showed no significant difference between the initial move- 
ments in the knees allocated to the three treatment groups (silicone, hydrocortisone, or hydrocortisone plus saline).

Mean changes in movement at the various assessment times are shown in Table I for the osteoarthritic knees and in Table II for the rheumatoid knees. The mean change from the initial baseline assessment for extension, flexion, and total range in degrees is recorded. In addition the mean change in range is expressed as a percentage of the initial reading.

\begin{tabular}{|c|c|c|c|c|c|c|}
\hline & $\begin{array}{c}1 \\
\text { week }\end{array}$ & $\begin{array}{c}2 \\
\text { weeks }\end{array}$ & $\begin{array}{c}3 \\
\text { weeks }\end{array}$ & $\begin{array}{c}6 \\
\text { weeks }\end{array}$ & $\stackrel{3}{3}_{\text {months }}$ & $\stackrel{6}{\text { months }}$ \\
\hline No. of observations & 21 & 21 & 21 & 22 & 22 & 22 \\
\hline \multicolumn{7}{|c|}{ Mean Change in Extension (in degrees) } \\
\hline $\begin{array}{l}\text { Overall change } \\
\text { Silicone } \\
\text { Hydrocortisone } \\
\text { Hydrocortisone + saline }\end{array}$ & $\begin{array}{r}0.91 \\
-0.29 \\
2.14 \\
0.86\end{array}$ & $\begin{array}{r}1 \cdot 33 \\
-0 \cdot 71 \\
2 \cdot 42 \\
2 \cdot 28\end{array}$ & $\begin{array}{l}2 \cdot 62 \\
0 \cdot 29 \\
4 \cdot 0 \\
3 \cdot 59\end{array}$ & $\begin{array}{l}1 \cdot 82 \\
0 \cdot 25 \\
3 \cdot 59 \\
1 \cdot 86\end{array}$ & $\begin{array}{r}0.82 \\
-0.35 \\
2.59 \\
0.43\end{array}$ & $\begin{array}{r}-0.68 \\
-1.87 \\
0.71 \\
-0.71\end{array}$ \\
\hline \multicolumn{7}{|c|}{ Mean Change in Flexion (in degrees) } \\
\hline $\begin{array}{l}\text { Overall change } \\
\text { Silicone } \quad . \\
\text { Hydrocortisone } \\
\text { Hydrocortisone + saline }\end{array}$ & $\begin{array}{r}6 \cdot 9 \\
2 \cdot 86 \\
11 \cdot 42 \\
6 \cdot 43\end{array}$ & $\begin{array}{r}7 \cdot 85 \\
3 \cdot 57 \\
11 \cdot 42 \\
8 \cdot 57\end{array}$ & $\begin{array}{l}8 \cdot 0 \\
5 \cdot 22 \\
9 \cdot 28 \\
9 \cdot 42\end{array}$ & $\begin{array}{l}7 \cdot 73 \\
6 \cdot 85 \\
8 \cdot 57 \\
7 \cdot 86\end{array}$ & $\begin{array}{l}6 \cdot 36 \\
3 \cdot 12 \\
7 \cdot 14 \\
8 \cdot 57\end{array}$ & $\begin{array}{l}5 \cdot 23 \\
1 \cdot 88 \\
8 \cdot 57 \\
5 \cdot 71\end{array}$ \\
\hline \multicolumn{7}{|c|}{ Mean Change in Range (in degrees) } \\
\hline $\begin{array}{l}\text { Overall change } \\
\text { Silicone } \ldots \\
\text { Hydrocortisone } \\
\text { Hydrocortisone }+ \text { - saline }\end{array}$ & $\begin{array}{r}7 \cdot 8 \\
2 \cdot 57 \\
14 \cdot 28 \\
7 \cdot 29\end{array}$ & $\begin{array}{r}9 \cdot 19 \\
2 \cdot 86 \\
15 \cdot 29 \\
10 \cdot 86\end{array}$ & $\begin{array}{l}10 \cdot 76 \\
5 \cdot 43 \\
14 \cdot 0 \\
12 \cdot 86\end{array}$ & $\begin{array}{r}9 \cdot 77 \\
7 \cdot 13 \\
12 \cdot 14 \\
10 \cdot 43\end{array}$ & $\begin{array}{l}6.95 \\
3 \cdot 35 \\
9 \cdot 0 \\
9 \cdot 0\end{array}$ & $\begin{array}{c}4 \cdot 32 \\
0 \\
7 \cdot 14 \\
4 \cdot 29\end{array}$ \\
\hline \multicolumn{7}{|c|}{ Mean Change in Range (percentage change from initial reading) } \\
\hline $\begin{array}{l}\text { Silicone } \ldots \\
\text { Hydrocortisone } \\
\text { Hydrocortisone + saline }\end{array}$ & $\begin{array}{r}1 \cdot 5 \\
18 \cdot 1 \\
10 \cdot 3\end{array}$ & $\begin{array}{r}1 \cdot 9 \\
18 \cdot 7 \\
16 \cdot 3\end{array}$ & $\begin{array}{r}5 \cdot 6 \\
18 \cdot 6 \\
20 \cdot 4\end{array}$ & $\begin{array}{r}7 \cdot 8 \\
15 \cdot 7 \\
14 \cdot 7\end{array}$ & $\begin{array}{r}3 \cdot 6 \\
11 \cdot 4 \\
14 \cdot 1\end{array}$ & $\begin{array}{r}-2 \cdot 7 \\
14 \cdot 6 \\
8 \cdot 4\end{array}$ \\
\hline
\end{tabular}

\begin{tabular}{|c|c|c|c|c|c|c|}
\hline & $\begin{array}{c}1 \\
\text { week }\end{array}$ & $\stackrel{2}{2}$ weeks & $\begin{array}{c}3 \\
\text { weeks }\end{array}$ & $\begin{array}{c}6 \\
\text { weeks }\end{array}$ & $\stackrel{3}{\text { months }}$ & $\begin{array}{c}6 \\
\text { months }\end{array}$ \\
\hline No. of observations .. & 43 & 43 & 41 & 49 & 47 & 49 \\
\hline \multicolumn{7}{|c|}{ Mean Change in Extension (in degrees) } \\
\hline $\begin{array}{l}\text { Overall change } \\
\text { Silicone } \\
\text { Hydrocortisone } \\
\text { Hydrocortisone + saline }\end{array}$ & $\begin{array}{l}3 \cdot 51 \\
3 \cdot 29 \\
2.91 \\
3 \cdot 92\end{array}$ & $\begin{array}{l}3 \cdot 91 \\
3 \cdot 7 \\
2 \cdot 91 \\
5 \cdot 0\end{array}$ & $\begin{array}{l}3 \cdot 93 \\
3 \cdot 82 \\
2 \cdot 27 \\
5 \cdot 7\end{array}$ & $\begin{array}{l}4 \cdot 13 \\
4 \cdot 0 \\
3 \cdot 66 \\
4 \cdot 66\end{array}$ & $\begin{array}{l}1 \cdot 88 \\
1 \cdot 64 \\
1 \cdot 67 \\
2 \cdot 37\end{array}$ & $\begin{array}{l}1 \cdot 22 \\
1 \cdot 17 \\
0 \cdot 33 \\
2 \cdot 35\end{array}$ \\
\hline \multicolumn{7}{|c|}{ Mean Change in Flexion (in degrees) } \\
\hline $\begin{array}{l}\text { Overall change } \\
\text { Silicone } \ldots \\
\text { Hydrocortisone } \\
\text { Hydrocortisone + }\end{array}$ & $\begin{array}{l}5 \cdot 58 \\
3 \cdot 23 \\
5 \cdot 83 \\
8 \cdot 21\end{array}$ & $\begin{array}{l}7.55 \\
5 \cdot 88 \\
6.66 \\
9 \cdot 64\end{array}$ & $\begin{array}{r}7 \cdot 93 \\
6 \cdot 18 \\
6 \cdot 36 \\
11.54\end{array}$ & $\begin{array}{l}6 \cdot 43 \\
6 \cdot 17 \\
5 \cdot 66 \\
6 \cdot 17\end{array}$ & $\begin{array}{l}5 \cdot 1 \\
6 \cdot 47 \\
3 \cdot 21 \\
5 \cdot 0\end{array}$ & $\begin{array}{l}3 \cdot 57 \\
3 \cdot 53 \\
2 \cdot 0 \\
5 \cdot 0\end{array}$ \\
\hline \multicolumn{7}{|c|}{ Mean Change in Range (in degrees) } \\
\hline $\begin{array}{l}\text { Overall change } \\
\text { Silicone } \quad . \\
\text { Hydrocortisone } \\
\text { Hydrocortisone + }\end{array}$ & $\begin{array}{r}9 \cdot 32 \\
6 \cdot 53 \\
8 \cdot 75 \\
13 \cdot 92\end{array}$ & $\begin{array}{r}10 \cdot 88 \\
8 \cdot 71 \\
8 \cdot 75 \\
14 \cdot 07\end{array}$ & $\begin{array}{r}12 \cdot 19 \\
10 \cdot 59 \\
8 \cdot 64 \\
17 \cdot 31\end{array}$ & $\begin{array}{r}11 \cdot 26 \\
11 \cdot 35 \\
9 \cdot 33 \\
13 \cdot 18\end{array}$ & $\begin{array}{l}7 \cdot 0 \\
8 \cdot 12 \\
5 \cdot 21 \\
7 \cdot 37\end{array}$ & $\begin{array}{l}4 \cdot 89 \\
4 \cdot 71 \\
2 \cdot 33 \\
7 \cdot 35\end{array}$ \\
\hline \multicolumn{7}{|c|}{ Mean Change in Range (percentage change from initial reading) } \\
\hline $\begin{array}{l}\text { Silicone } \\
\text { Hydrocortisone } \\
\text { Hydrocortisone + saline }\end{array}$ & $\begin{array}{l}10 \cdot 1 \\
11 \cdot 9 \\
17 \cdot 6\end{array}$ & $\begin{array}{l}13 \cdot 3 \\
11 \cdot 3 \\
19 \cdot 4\end{array}$ & $\begin{array}{l}15 \cdot 0 \\
10 \cdot 7 \\
22 \cdot 9\end{array}$ & $\begin{array}{l}14 \cdot 9 \\
12 \cdot 3 \\
17 \cdot 6\end{array}$ & $\begin{array}{r}11.3 \\
6.9 \\
11.0\end{array}$ & $\begin{array}{r}6 \cdot 3 \\
3 \cdot 3 \\
11 \cdot 4\end{array}$ \\
\hline
\end{tabular}

With only eight, seven, and seven osteoarthritic knees in each of the treatment groups, changes need to be large in order to attain significance, but it will be seen that the largest differences occurred at three weeks. Similarly on the rheumatoid knees where there were only 17, 15, and 17 knees in each treatment group, large differences are required for significance. The largest difference occurred at the third week. In view of this, differences between the three treatment subgroups at the third week after injection were tested for significance. In the osteoarthritic knees differences were too small to attain statistical significar:e though they suggest that silicone had no advantage over the other two types of injection so far as increase in movement was concerned. The effect on mean range of movement in degrees and on percentage increase in range of hydrocortisone and hydrocortisone plus saline was very similar $(0.9>\mathrm{P}>0.8)$ at three weeks.

In rheumatoid knees hydrocortisone plus saline was significantly better than hydrocortisone alone for mean change in range $(0.05>\mathrm{P}>0.02)$ and for mean percentage change $(0.02>\mathrm{P}>0.01)$.

There was borderline significance in favour of hydrocortisone plus saline over hydrocortisone alone for change in extension $(0.1>\mathrm{P}>0.05)$ and a suggestion that hydrocortisone plus saline was also more effective than hydrocortisone alone as regards improving flexion in the rheumatoid knee $(0.2>\mathrm{P}>0.1)$.

Hydrocortisone plus saline was significantly better than silicone in promoting flexion $(0.05>P>0.02)$ and slightly better $(0.1>\mathrm{P}>0.05)$ with regard to absolute change in range.

No real statistical difference could be shown between silicone and hydrocortisone, though the results appear to favour hydrocortisone.

There was no correlation between change in movement and change in quadriceps muscle strength. Eighteen of the 22 osteoarthritic and 42 of the 49 rheumatoid legs were able to lift progressively heavier weights throughout the assessment period. This improvement occurred equally between the three treatment groups and was thought to reflect the assiduity with which the exercises were practised at home.

No relationship could be found between change in movement and change in pain. Change in pain was similar in the three treatment groups. At three weeks 14 of the 22 osteoarthritic and 30 of the 49 rheumatoid knees were pronounced to be less painful. In no knee was there any change radiologically six months after injection, and we were unable to correlate improvement or the lack of it with the $x$-ray findings.

Only two patients, one of whom had received hydrocortisone and the other of whom had received silicone, had increased pain for 24 hours following the injection. No other side-effects were observed.

\section{Discussion}

Physiotherapy preceded by one of the three intra-articular injections-silicone, hydrocortisone acetate, or hydrocortisone plus saline-appears to increase the movement in stiff, dry, creaky knees which are the site of chronic arthritis. Silicone is not more effective than hydrocortisone acetate in osteoarthritic or in rheumatoid knees. In rheumatoid knees, however, hydrocortisone plus saline is significantly better than hydrocortisone alone or than silicone. The explanation of this finding may be that better penetration into the interstices of a chronic rheumatoid knee joint is obtained by increasing the volume of the anti-inflammatory substance. Further work is being done to confirm this.

The increase in movement was maximal at three weeks. Quadriceps strength was increased in most patients and the majority claimed less pain. The effect on pain was evenly distributed throughout the three treatment subgroups but did not correlate with objective findings.

Thirteen of the 22 osteoarthritic knees were judged to be less painful after the first week, but only 8 of the $13(62 \%)$ had achieved a $10 \%$ increase in range. At the third week only 10 out of $14(71 \%)$ and at the twenty-fourth week only 5 out of $7(71 \%)$ where less pain was claimed had a $10 \%$ or more increase in range.

Of the 49 rheumatoid knees, 34 were less painful after the first week, but in only 21 of these $(62 \%)$ was there an increase in range of $10 \%$ or more. At three weeks only 20 out of $30(67 \%)$ and at six months only 6 out of $16(37.5 \%)$ where less pain was claimed had a similar increase in range.

It is thought that these findings are in keeping with the generally accepted theory that patients with chronic arthritis are placebo-reactors.

We wish to thank our colleagues for referring suitable patients and are indebted to the Arthritis and Rheumatism Council for generous aid towards secretarial help. Dr. E. Lewis-Faning advised on the design of this trial and is responsible for the statistical analysis, and Mr. B. Helal kindly demonstrated his technique to us. Finally, we wish to thank Mr. G. Bryan, the chief pharmacist, for his help.

\section{REFERENCES}

American Academy of Orthopaedic Surgeons (1966). Foint Motion: Method of Measuring and Recording, p. 66. Edinburgh, Livingstone.

Helal, B., and Karadi, B. S. (1968). Annals of Physical Medicine, 9, 334. 